\title{
INFRASTRUCTURE OF INNOVATION ENTERPRISE: FEATURES OF FORMATION AND REGULATION IN MODERN MARKET CONDITIONS
}

\author{
Iryna Hnatenko ${ }^{1}$, Ihor Kuksa ${ }^{2}$, Inna Naumenko ${ }^{3}$, Denis Baldyk ${ }^{4}$, \\ Viktoriia Rubezhanska ${ }^{5}$
}

\author{
${ }^{1}$ Assoc. Prof. PhD of Econ. Kyiv National University of Technologies and Design. \\ Nemyrovycha-Danchenka str. 2. Kyiv. Ukraine, \\ Phone Number+380661076939, E-mail address q17208@ukr.net \\ ${ }^{2}$ Prof. Dr Sc. (Ekon). Luhansk National Agrarian University. \\ Bolshaya Sadova str. 2. Starobilsk. Ukraine. \\ Phone Number+380506475207, E-mail address igor.kuksa.23@gmail.com \\ ${ }^{3}$ PhD of Econ. Luhansk National Agrarian University. Bolshaya Sadova str. 2. Starobilsk. Ukraine. \\ Phone Number+380508729510,E-mail addressnaum.inna.28@gmail.com \\ ${ }^{4}$ PhD of Econ. Luhansk National Agrarian University. Bolshaya Sadova str. 2. 92702. Starobilsk. Ukraine. \\ Phone Number+380955183937.E-mail address baldykdenis@gmail.com \\ ${ }^{5}$ PhD of Econ. Luhansk Taras Shevchenko National University. Gogol str. 1. 92700. Starobilsk. Ukraine. \\ Phone Number+380953081789. E-mail address rubezhiik@gmail.com
}

Received 04 012020-01-04, Accepted 23032020

\begin{abstract}
Innovative entrepreneurship in a market economy becomes an active factor in economic development, commercialization, creative activity of new technological ideas developers. The operation of an extensive network of innovation infrastructure, elements of which are implemented in specific forms of economic activity, is a necessary factor for the successful development of innovation entrepreneurship. The purpose of the article is to study the essence of the concept of "infrastructure of innovation entrepreneurship" and to develop basic recommendations for its formation for further use by public authorities in the process of promoting the development of innovation entrepreneurship in the country. In the article the content of the categories "innovative entrepreneurship" is defined. To achieve this goal, the following methods of scientific research were used: systematic analysis; abstract-logical method; graphical method. According to the results of the study, the suggested recommendations for the formation of innovation entrepreneurship infrastructure at the national and regional level can be used by public authorities in the process of creating a single mechanism for regulating innovation infrastructure, which would ensure interaction between business, public authorities, science and end-users of an innovation product (service) at all stages of development and implementation of innovation projects.
\end{abstract} model.

Key words: innovation, innovation enterprise, infrastructure of innovation entrepreneurship, state regulation,

JEL Codes M21, O32.

\section{Introduction}

Innovative entrepreneurship in a market economy becomes an active factor in economic development, commercialization, creative activity of new technological ideas developers. Innovation enterprises provides employment for the active part of the scientific and technical community and most effectively and quickly transfers the knowledge previously accumulated in science to the market of goods and services based on intellectual property. For the successful development of innovation entrepreneurship, it is vital to have a stable functioning innovation infrastructure, elements of which will be implemented in specific forms of economic activity.

Copyright (C) 2020. Published by Vytautas Magnus University. This is an open access article distributed under the terms of the Creative Commons Attribution Non-Commercial 4.0 (CC BY-NC 4.0) license, which permits unrestricted use, distribution, and reproduction in any medium provided the original author and source are credited. The material cannot be used for commercial purposes. 
This will ensure the availability of logistical, information, financial, labor and other resources - in other words, factors of production, without which the process of reproduction in business is impossible. The study of the process of formation and functioning of innovation entrepreneurship is devoted to the works of many scientists who emphasize the need to promote the development of an extensive infrastructure network that would provide comprehensive support to innovation enterprises (Abdu, Jibir, 2018; Bresciani, Ferraris, 2016; Daksa, Yismaw, Lemessa, Hundie, 2018; Hashi, Stojcic, 2013; Raymond, St-Pierre, 2010). It should be noted that the essence of the innovation entrepreneurship infrastructure is also the subject of research by a number of scientists, but the only vision of the content of this concept has not been formed yet. The basic approaches to treating innovation infrastructure are to consider infrastructure as a complex or a set of industries, enterprises, objects, activities or conditions. Thus, Rosenstein - Rodan (1961) refers to infrastructure as basic economic industries (energy, transport, communication), the development of which is preceded by fast-paced investment as well as direct industrial investment. A similar view is observed at Singer (1998), according to which investment in infrastructure should contribute to the growth of national income, which in the future should lead to increased investment in certain sectors of the economy. According to Jochimsen (1966), infrastructure is a set of material, institutional and individual conditions at the disposal of business entities that correspond to the equalization of income associated with equal productivity of factors that allow for the appropriate allocation of resources to ensure full integration and the highest level of economic activity.

The study of state regulation of innovation infrastructure, as well as the specific features of its formation and functioning, are quite relevant research areas conducted by scientists in different countries of the world. For example, Woolley (2014) demonstrates by the example of the nanotechnology as elements of infrastructure emerge and are configured through systemic coevolution. Research results reflect the process of transforming individual elements into a single infrastructure through the interaction and interdependence of private and public organizations and institutions (Woolley, 2014). In an article by Guo, Jiang (2016) reflects the importance of government regulation for infrastructure and entrepreneurship innovation, as exemplified by the Innovation Fund for Small and Medium-Sized Enterprises, which is one of the largest government programs supporting R\&D activities in China. The impact of government subsidies on the investment behavior of enterprises in the R\&D sector (namely, in the renewable energy sector) is considered in a scientific paper by Yua, Guo, Le-Nguyen, Barnesc, Zhanga (2016). Szczygielski, Grabowski, Pamukcu, Tandogan (2017) investigated the impact of state grants on the innovation performance of Turkish and Polish enterprises and found a positive effect of state aid on innovation entrepreneurship in both countries. Gamidullaeva (2018) searched for ways to integrate innovation ecosystem concepts with innovation intermediation theory, identified specific types of innovation intermediation and its main mechanisms aimed at creating an efficient infrastructure and ensuring the stable functioning of the innovation ecosystem. The Balázs (1995) study evaluated the innovative potential of new organizational forms of management and understanding of their functioning in newly created innovative systems to enhance knowledge flow into industry through academic and university research. Hung, Mondejar (2005) in their scientific work presented the results of the study of the corporate governance connection with the development of innovative entrepreneurship in a large Asian city. An article by Kokkonen, Tuohino (2007) confirmed that innovation in the networks of small and medium-sized tourism enterprises is a synthetic process consisting of the interconnection of innovative products, processes and resources. The Turkina, Oreshkin, Kali (2019) study focuses on the empirical analysis of the productivity of innovative firms in regional innovation clusters, which found that liaison with other innovation enterprises, research institutions and universities helps to increase the level of competitiveness of these enterprises.

Giving credit to the aforementioned scientific achievements, it should be noted that the approaches to systematic management of the innovation enterprise and the process of its infrastructure formation are not substantiated. In this regard, the purpose of the article is to investigate the essence of the concept of "innovation entrepreneurship infrastructure" and to develop basic recommendations 
for its formation for further use by public authorities in the process of promoting innovation entrepreneurship in the country. In order to achieve this goal, the following tasks were set and solved: the content of the categories "innovative entrepreneurship" was investigated; approaches of scientists to definition of the concept «infrastructure of innovation enterprise» are considered; the model of innovation entrepreneurship infrastructure is built and its main functions are allocated; recommendations for the formation of innovation infrastructure are proposed.

Object of the research is an infrastructure of innovation entrepreneurship; subject of research is organizational and economic relations resulting from the management of an infrastructure of innovation entrepreneurship.

The theoretical and methodological basis of the study is the fundamental scientific work of leading scientists on the study of innovation, innovation entrepreneurship and the development of its infrastructure. In the course of the research, the following methods of cognition of economic phenomena and processes were used to solve the problems posed in the work: systematic analysis to reveal the foundations of the conceptual apparatus of the innovative entrepreneurship infrastructure; abstract-logical method - for realization of theoretical generalizations about typical features of functioning of innovative enterprise infrastructure; graphical method - for visual representation of theoretical and analytical material on reflection of the basic tendencies of development and functioning of innovative enterprise infrastructure.

The suggested recommendations for the formation of innovation entrepreneurship infrastructure at the national and regional level can be used by public authorities in the process of creating a single mechanism for regulating innovation infrastructure, which would ensure interaction between business, public authorities, science and end-users of an innovation product (service) at all stages of development and implementation of innovation projects to promote the development of an innovation economy in the country as a whole.

\section{Research results and discussion}

The specific innovation orientation of development, which characterizes modern economic processes, puts forward new requirements for the content, organization, forms and methods of economic activity. With the innovation orientation of economic growth, models of the research process of creation of new scientific knowledge and procedures of new intellectual products emergence occupy the main place. Increasingly significant influence on reproductive processes is carried out by scientific knowledge, skills, software, patents and licenses. In addition, national economic development trends also indicate an increased impact of innovation on economic development. The requirements of the market dictate the need to create conditions for widespread use of innovations, enhancement of innovation activity. The world experience of innovation development shows that innovation is the optimal way of scientific and technological re-equipment and gradual diversification of production. Therefore, the development and implementation of innovation play a major role in entrepreneurship (Kuksa, Shtuler, Orlova-Kurilova, Hnatenko, Rubezhanska, 2019).

The creation of technical and technological capabilities and the availability of competitive staff makes it possible to carry out scientific research at the enterprise, to generate innovation ideas on the basis of which to develop innovation projects that will change the technology of available goods and services production, as well as to master the production of new types of products and services (Kuksa, Hnatenko, Orlova-Kurilova, Moisieieva, Rubezhanska, 2019).

In our opinion, innovation entrepreneurship is a process of creation and commercial use of technique and technological innovations or a special innovative process of management, which is based on the constant search for new opportunities, orientation on innovation. Innovation entrepreneurship is related to the entrepreneur's willingness to take the risk of implementing a new project or improving an existing one, and the resulting financial, moral and social responsibility (Hnatenko, Rubezhanska, Parchomenko, 2019). It should also be noted that due to the riskiness and 
most often non-traditional specific activity, innovation enterprises become bankrupt at the beginning of their development.

At the same time, an effectively functioning innovation business infrastructure provide the differentiation the nature of regulation measures by innovation enterprises through appropriate organizational and legal provision of comprehensive and targeted assistance in different directions: (information, consulting, training, forecasting - analytical, scientific and technical, technological, financial, property).

In our opinion, the innovation entrepreneurship infrastructure is a complex of interconnected economic elements, structured according to the principle of "technological corridor", organizationally and legally servicing and providing realization of innovation activity of the enterprise aimed at transformation of progressive scientific knowledge into a new market product. Given that the elements of infrastructure are the "channels" through which the necessary resources are communicated to their consumers - entities of innovation entrepreneurship, the infrastructure model of such entrepreneurship can be depicted with the help of Figure 1.

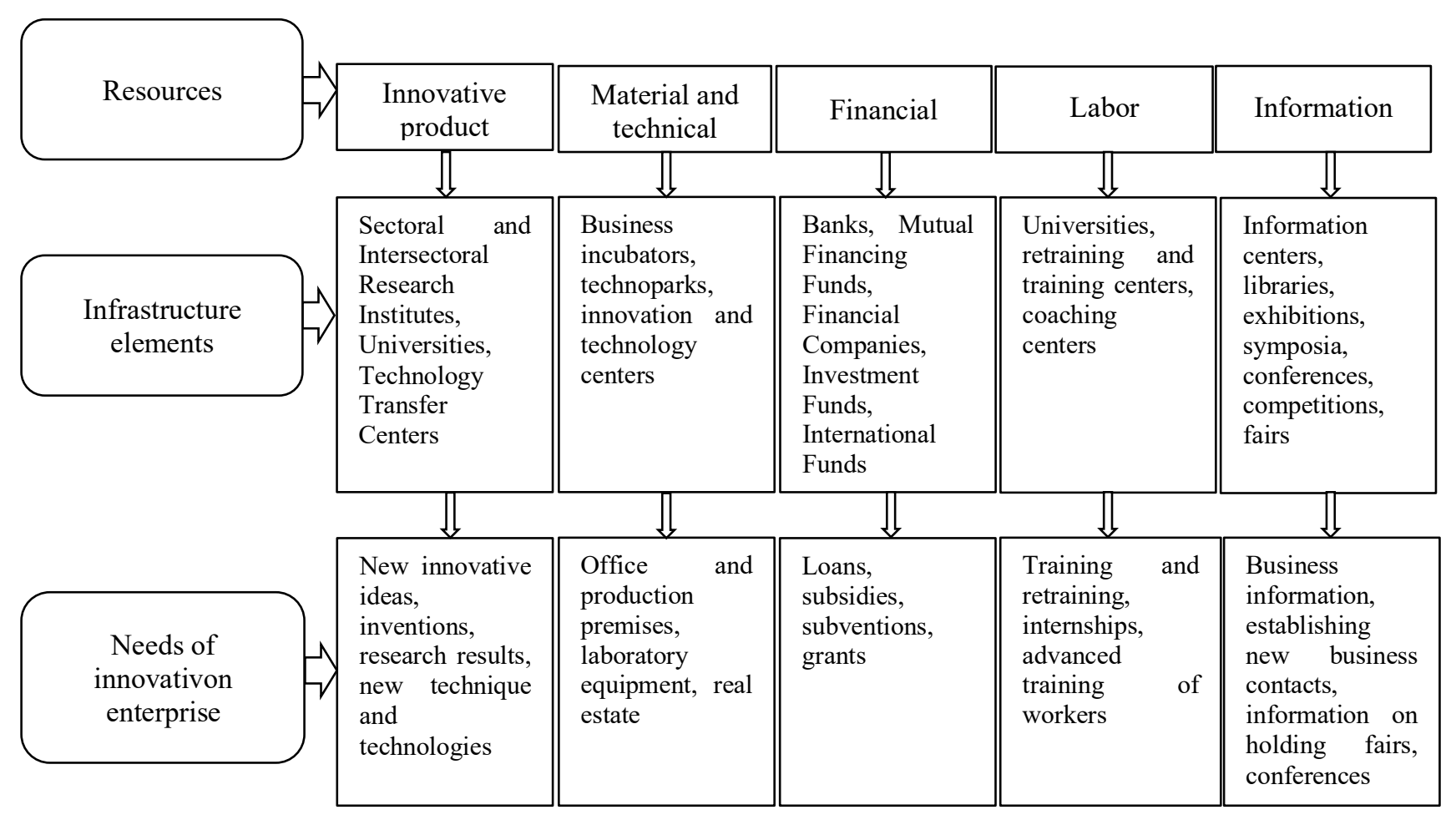

Figure 1. Model of innovation entrepreneurship infrastructure

The system of innovation entrepreneurship infrastructure should consist of several complementary elements, which together determine the connection of scientific and technical activity with production in market conditions (covering all stages of innovation enterprise development).

At the same time, at each stage of innovation development, the needs of the innovation enterprise will change, which will require other conditions for providing innovative activity by the infrastructure. That is, the functions of innovation entrepreneurship infrastructure largely depend on the stage of innovation development (Figure 2). Presented in Figure 2, the list of innovative entrepreneurship infrastructure features required at each stage of innovation development can be expanded significantly.

This fact should be considered in the process of formation of the said infrastructure. In turn, the formation and development of infrastructure for innovation entrepreneurship is impossible without the active participation of the state. It is explained by the fact that in modern conditions successful competition of Ukrainian enterprises with leading players in the world market is 
impossible without the creation and continuous improvement of the national innovation infrastructure.

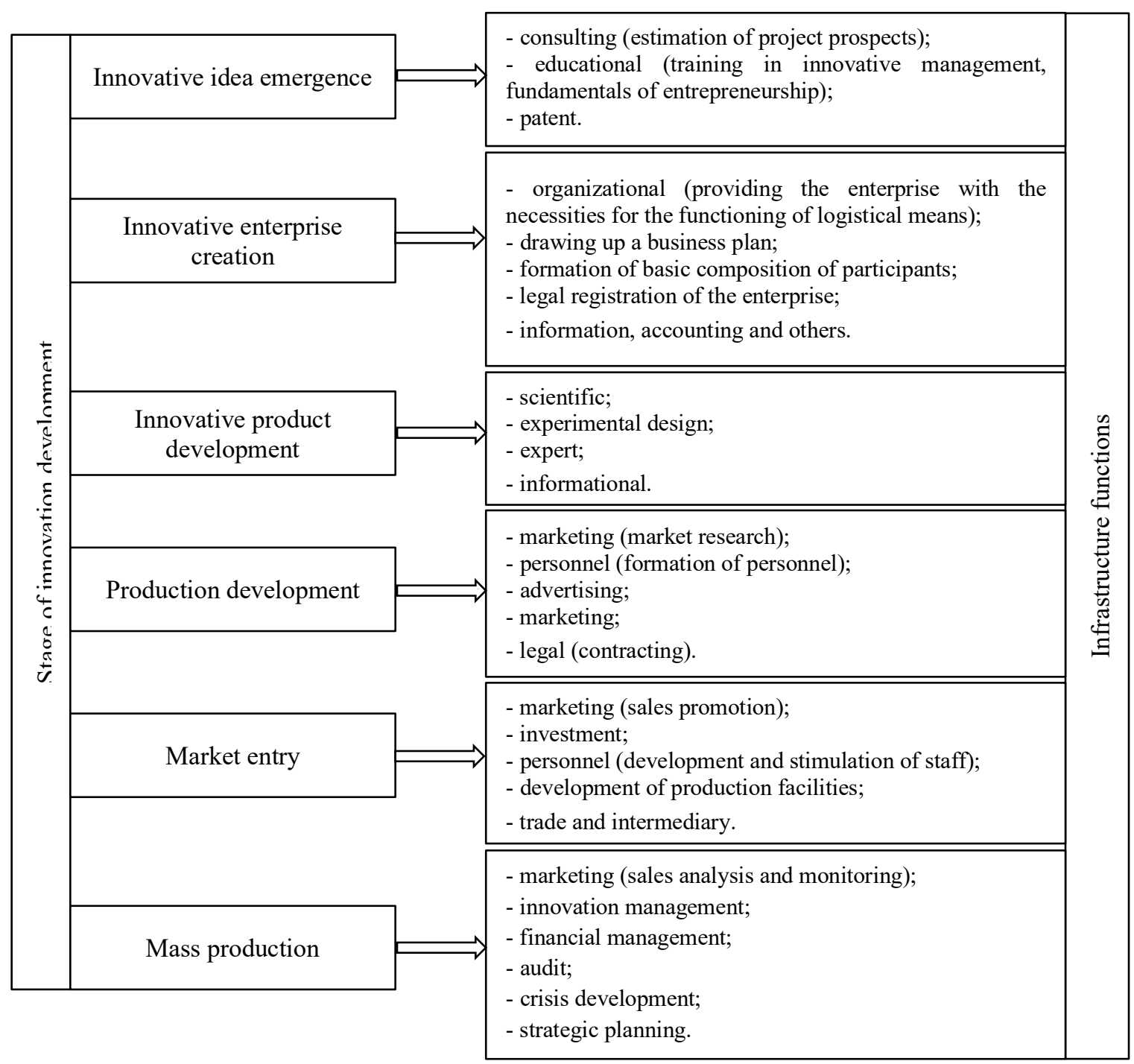

Figure 2. Functions of innovation entrepreneurship infrastructure

It should also be noted that any innovation enterprise has the appropriate features of operation depending on the region of its location. Therefore, the success of innovation enterprises depends not only on state support, but also on the institutional and business environment, social infrastructure, availability of the necessary personnel with the appropriate level of qualification, etc., established at a certain region level.

Thus, the infrastructure of innovation entrepreneurship must be shaped and regulated at both national and regional levels. The main recommendations for efficient formation of innovation entrepreneurship infrastructure and national and regional levels are shown in Table 1. 
Table 1. Recommendations for the formation of innovation entrepreneurship infrastructure

\begin{tabular}{|c|c|}
\hline National level & Regional level \\
\hline $\begin{array}{l}\text { - transfer of state support functions to intermediaries } \\
\text { (independent agencies, foundations operating as private } \\
\text { non-profit organizations) in order to objectively evaluate } \\
\text { the quality of innovative projects and their associated } \\
\text { risks, and reduce the level of corruption in the process of } \\
\text { providing state support to enterprises for implementation } \\
\text { their innovative projects; } \\
\text { - decentralization of state support through the use of } \\
\text { different channels of promotion of innovative activity } \\
\text { (formation of specialized institutes of support and } \\
\text { development extensive network); } \\
\text { - establishment of a network of innovation business } \\
\text { infrastructure facilities that would support innovative } \\
\text { projects at all stages of development, ensure the exchange } \\
\text { of information between all infrastructure objects and the } \\
\text { relationship between business and research and } \\
\text { development. }\end{array}$ & $\begin{array}{l}\text { - involvement of interested scientific and educational } \\
\text { organizations, enterprises, development institutes for } \\
\text { elaboration of innovative development strategies and } \\
\text { regional programs; } \\
\text { - activation of innovation activity of small and medium- } \\
\text { sized businesses by providing state financial assistance to } \\
\text { economic entities; } \\
\text { - promoting the formation and development of innovative } \\
\text { infrastructure (business incubators, techno parks, } \\
\text { technology transfer centers, regional venture funds); } \\
\text { - stimulating the production of innovative products } \\
\text { through the use of a public procurement mechanism; } \\
\text { - development of educational services in the field of } \\
\text { innovative technologies and innovative management. }\end{array}$ \\
\hline
\end{tabular}

Thus, state regulation at national and regional levels should aim at creating an optimal infrastructure for innovation entrepreneurship that would be clearly designed, mobile, adaptable to changing requirements and goals, understandable and easily accessible to businesses. In our opinion, it is possible to solve this problem by creating a unified mechanism for managing the development of innovation infrastructure that would carry out economic, organizational, legal regulation and control over the activity of innovation enterprises, as well as ensure effective interconnection and exchange of necessary information and resources between all objects of innovation entrepreneurship infrastructure.

\section{Conclusion}

The conducted research makes it possible to state that the formation of an effective infrastructure for its support is one of the priority tasks within the framework of implementation of measures to activate innovation activity of entrepreneurship in the country. Ensuring the effectiveness of the activity of public authorities in the development of the said infrastructure requires consideration of the regional specificity of the functioning of enterprises, which necessitates the development of measures to ensure the development of innovation entrepreneurship infrastructure at both national and regional levels, which will allow to create prerequisites for the transformation of current potential enterprises incentives. It is the regional level where the most flexible coordination of communications between enterprises and the research sector of the economy and the most flexible adaptation of infrastructure to changing demand for its services are possible.

The proposed recommendations for the formation of innovation entrepreneurship infrastructure at national and regional level can be used by public authorities in the process of creating a single mechanism for regulating innovation infrastructure, which would ensure interaction between business, public authorities, scientists and consumers at all stages of development and implementation of innovative projects, an innovative product (service) to promote the development of an innovation economy in the country as a whole.

\section{References}

Abdu, M., Jibir, A. (2018). Determinants of firm's innovation in Nigeria // Kasetsart Journal of Social Sciences. Vol.39: 448-456. - https://doi.org/10.1016/j.kjss.2017.07.006 [01 01 2020]. 
Balázs, K. (1995). Innovation Potential Embodied in Research Organizations in Central and Eastern Europe // Social Studies of Science. Vol.25. No.4: 655-683. https://doi.org/10.1177/030631295025004004 [01 01 2020].

Bresciani, S., Ferraris, A. (2016). Innovation-receiving subsidiaries and dual embeddedness: impact on business performance // Baltic Journal of Management. Vol.11. No.1: 108-130.

Daksa, M., Yismaw, M., Lemessa, S., Hundie, S. (2018). Enterprise innovation in developing countries: an evidence from Ethiopia // Journal of Innovation and Entrepreneurship. Vol.7. https://doi.org/10.1186/s13731-018-0085-4 [01 01 2020].

Gamidullaeva, L. (2018). Towards combining the innovation ecosystem concept with intermediary approach to regional innovation development // International Journal of Economics \& Business Administration. Vol.VI. No.1: 39-53.

Guo, D., Guo, Y., Jiang, K. (2016). Government-subsidized R \& D and firm innovation: evidence from China // Research Policy. Vol.45. No.6: 1129-1144. https://doi.org/10.1016/j.respol.2016.03.002 [01 01 2020].

Hashi, I., Stojcic, N. (2013). Knowledge spillovers, innovation activities, and competitiveness of industries in EU member and candidate countries // Economic Annals. Vol.58. No.198: 7-34. https://doi.org/10.2298/EKA1398007H [01 01 2020].

Hnatenko, I., Rubezhanska, V., Parchomenko, O. (2019). Formation of the potential of innovative enterprise by improvement of labor market infrastructure // Problems of systematic approach in economy. Vol.3. No.71: 179-184.

Hung, H., Mondejar, R. (2005). Corporate directors and entrepreneurial innovation: an empirical study // The Journal of Entrepreneurship. Vol.14. No.2: 117-129. https://doi.org/10.1177/097135570501400203 [01 012020$].$

Jochimsen, R. (1966). Theorie der Infrastrutur. - Tubungen, 284 p.

Kokkonen, P., Tuohino, A. (2007). The challenge of networking: analysis of innovation potential in small and medium-sized tourism enterprises // The International Journal of Entrepreneurship and Innovation. Vol.8. No.1: 44-52. https://doi.org/10.5367/000000007780007407 [01 01 2020].

Kuksa I., Shtuler I., Orlova-Kurilova O., Hnatenko I., Rubezhanska V. (2019). Innovation cluster as a mechanism for ensuring the enterprises interaction in the innovation sphere // Management Theory and Studies for Rural Business and Infrastructure Development. Vol.41. No.4: 487-500. - https://doi.org/10.15544/mts.2019.39 [01 01 2020].

Kuksa, I., Hnatenko, I., Orlova-Kurilova, O., Moisieieva, N., Rubezhanska, V. (2019). State regulation of innovative employment in the context of innovative entrepreneurship development // Management Theory and Studies for Rural Business and Infrastructure Development. Vol.41. No.2: 228-236. - https://doi.org/10.15544/mts.2019.19 [01 01 2020].

Raymond, L., St-Pierre, J. (2010). R\&D as a determinant of innovation in manufacturing SMEs: an attempt at empirical clarification // Technovation. Vol.30. No.1: 48-56. https://doi.org/10.1016/j.technovation.2009.05.005 [01 01 2020].

Rosenstein - Rodan, P. (1961). Notes on the Theorie of the «Big Push». Economic Development for Latin America. - London, $345 \mathrm{p}$.

Singer, H. (1998). Growth, Development, and Trade: Selected Essays of Singer, Hans Wolfgang. - Edward: Elgar Publishing, Incorporated, 501 p.

Szczygielski, K., Grabowski, W., Pamukcu, T., Tandogan, V. (2017). Does government support for private innovation matter? Firm-level evidence from two catching-up countries // Research Policy. Vol.46. No.1: 219-237. - https://doi.org/10.1016/j.respol.2016.10.009 [01 012020$]$.

Turkina, E., Oreshkin, B., Kali, R. (2019). Regional innovation clusters and firm innovation performance: an interactionist approach // Regional Studies. Vol.53. No.8: 1193-1206. https://doi.org/10.1080/00343404.2019.1566697 [01 01 2020]. 
Woolley, J. (2014). The Creation and Configuration of Infrastructure for Entrepreneurship in Emerging Domains of Activity // Entrepreneurship Theory and Practice. Vol.38. No.4: 721-747. https://doi.org/10.1111/etap.12017 [01 01 2020].

Yua, F., Guo, Y., Le-Nguyen, Kh., J.Barnesc, St., Zhanga, W. (2016). The impact of government subsidies and enterprises' R\&D investment: A panel data study from renewable energy in China // Energy Policy. Vol.89. No.106-113. - https://doi.org/10.1016/j.enpol.2015.11.009 [01 01 2020]. 